\title{
Forest biodiversity in a changing climate: which logic for conservation strategies?
}

\author{
Harald Schaich • Mirjam Milad
}

Published online: 27 April 2013

(C) Springer Science+Business Media Dordrecht 2013

\begin{abstract}
Climate change has direct and indirect impacts on forest ecosystems worldwide. In this context, changing site conditions and altered disturbance regimes as well as forest management responses are challenging the conservation of biodiversity in forests. Climate-induced dynamics and uncertainties related to future forest ecosystem development are calling into question current conservation strategies and concepts. Given the longevity of trees, slow development rates of forest ecosystems and slow migration rates of many forest species, the planning of adaptation measures in response to climate change are especially difficult though highly important for forest biodiversity conservation. This paper introduces a special issue with eight contributions which deal with a variety of aspects of forest biodiversity conservation in the face of climate change. More specifically, the papers address direct impacts of climate change on forest biodiversity, adaptation measures for forest and conservation management, as well as resulting challenges for conservation strategies and concepts. In conclusion, adaptation measures that enhance diversity and provide different options for future action, thereby maintaining ecosystems' resilience, as well as conservation management operating on a landscape level, are promoted as being beneficial for coping with uncertainties related to climate change. Adaptive management, which constantly reviews conservation goals and measures, and which takes into account both science-based and local ecological knowledge on climate change can be a valuable tool to inform decisions for forest biodiversity conservation.
\end{abstract}

Keywords Adaptive management - Biodiversity - Climate change $\cdot$ Conservation · Ecosystem services $\cdot$ Forest management $\cdot$ Methodology

\footnotetext{
H. Schaich $(\varangle) \cdot$ M. Milad

Chair for Landscape Management, Institute of Earth and Environmental Sciences,

Faculty of Environment and Natural Resources, University of Freiburg,

Tennenbacher Str. 4, 79106 Freiburg, Germany

e-mail: harald.schaich@landespflege.uni-freiburg.de
} 


\section{Introduction}

Climate change will influence forest biodiversity on multiple levels. Accordingly, direct and indirect impacts of climate change and possible means of adaptation feature prominently in research and debates on conservation and forest management all over the world. However, information is still attended by considerable uncertainties, which are, on the one hand, related to climatic development itself and its regional variation and, on the other hand, to forest ecosystems' responses and adaptive capacities (Milad et al. 2012b). Direct influences of climate change on forest ecosystems include both changes in climatic factors (e.g. surface temperature, precipitation regimes) and in the occurrence and intensity of extreme events, such as drought and heat waves, wind, heavy precipitation and floods. Due to their stochastic nature, it is particularly difficult to draw conclusions about extreme events. However, over recent decades, evidence of modifications in frequency and intensity of extreme weather events has mounted (Easterling et al. 2000; Jentsch et al. 2007). As a consequence, secondary disturbance events such as forest fires, pests or insect calamities will also be altered and different events such as the occurrence of drought and forest fires may interact and amplify each other (Flannigan et al. 2009). It becomes apparent that forest diversity-the variation in species, genes, habitats and structures and thus also in processes and functions-will be affected in complex ways and at different spatial and temporal levels (Milad et al. 2011). Site conditions and thus the appropriateness of habitats for certain species will be subject to change. Consequently, shifts in species' ranges are projected or have already been observed (Parmesan 2006; Buse et al. 2013), which may, at a local level, lead to new species compositions (Keith et al. 2009), but may also increase the risk of extinctions where suitable habitat is absent or unattainable (Parmesan 2006; Thomas et al. 2004). Modifications of the termination of phenological phases have been observed and are further expected in the future, which may additionally lead to discrepancies in interrelating phases of different species, e.g. in terms of foraging, reproduction or pollination (Penuelas and Filella 2001).

Above all, forest management has to face changes in tree species' suitability. While some species may be favored by mild and dry climatic conditions, others may be deprived and adaptive responses are likely to differ throughout species ranges, depending on the specific geographic location of populations or individuals (Rehfeldt et al. 2001). In particular, adaptation pressure and genetic potential may vary considerably at the leading and the rear edge of a species range (Hampe and Petit 2005). Different statements on the local appropriateness and adaptive capacity of tree species may complicate future tree species choice (Milad et al. 2012a). Given that forest ecosystems are characterized by long development rates, longevity of tree species and comparatively slow migration rates of many species (Jump and Penuelas 2005), future management decisions will be hindered.

Studies of the impacts of climate change on forest biodiversity, related consequences and the upcoming challenges for forest conservation strategies and policies were topics of an international conference held at the University of Freiburg in 2011. In this issue we present selected papers from different parts of the world, which deal with the quantification of climate change impacts on forest biodiversity, address adaptation measures in forest and conservation management or tackle the emerging challenges for conservation strategies and instruments that are brought about by climate change. 


\section{Challenges posed by climate change for biodiversity conservation in forests}

What are the overarching challenges for biodiversity conservation in forests posed by climate change? Major challenges arise from the increase in climate dynamics and thus also site conditions and the high degree of uncertainty and complexity related to climate change. Given the high projected rates of change, concepts based on static or historic conditions are likely to become infeasible (Perera et al. 2006; Milad et al. 2011), while dynamic approaches will become increasingly important (Milad et al. 2012b). Evaluation schemes and references for biodiversity conservation, such as Red Lists and their classifications or common definitions of nativeness will become increasingly problematic.

Conservation attempts aiming at the location-specific protection of species or the maintenance of specific species compositions will be questioned, and this may also influence concepts of protected areas and nature reserves (Hannah et al. 2007; Skov and Svenning 2004). Nevertheless, protected areas will continue to be an important conservation instrument and may even gain importance, for example regarding their role in buffering additional stresses as well as providing habitat for different species and changing species compositions. Conservation scientists thus call for an extension of the area currently under protection as well as an adjustment to the conceptualization and management of existing reserves (Hannah et al. 2007; Hossell et al. 2003).

Impacts of climate change on forest biodiversity may differ regionally and locally. In areas where forest conditions were previously uniform, an increase in stochastic events and dynamic processes may enhance diversity in structures and species (Jentsch and Beierkuhnlein 2008). Yet, globally, conservation of forest biodiversity is expected to become even more difficult in the light of climate change and related uncertainties. In addition, conservation objectives have to be developed and negotiated against a variety of societal demands for other ecosystem services (Schaich 2013). Both conflicts and synergies may arise from managing forests for timber, biodiversity conservation as well as for carbon sequestration, of which the latter is currently promoted by international financing mechanisms to reduce emissions from deforestation and forest degradation (REDD+) (Pistorius et al. 2012). The development of biodiversity safeguards and indicators as well as their consequent integration into forest management and respective incentive-based instruments for enhancing forest ecosystem services is therefore required (Schaich and Konold 2012; Caparros and Jacquemont 2003).

\section{Conference and papers on forest biodiversity conservation in times of climate change}

In spite of remaining uncertainties concerning the future impacts of climate change, there is a distinct need to generate more knowledge about the specific ways in which these will affect forest species and development processes. Moreover, it is important to reassess and refine strategies for the conservation of forest biodiversity. To address and discuss the challenges posed by climate change to forest biodiversity conservation from a global perspective, the Institute for Landscape Management and the Institute of Forest- and Environmental Policy of the University of Freiburg organized an international conference, which was held in September 2011 in Freiburg (Germany). The conference was an outcome of a joint research project of both Institutes on forests conservation and climate change, which was commissioned by the Federal Agency for Nature Conservation of Germany (BfN). The conference pursued an interdisciplinary and international approach aimed at the combination of both conservation and political science perspectives and the 
international exchange and comparison of experiences. Overall, 32 selected papers were presented by participants from 18 countries in two thematic sessions. Paper sessions were accompanied by plenum sessions with key note lectures from Jeffrey McNeely (IUCN), Benjamin Cashore (Yale University), Marcus Lindner (European Forest Institute) and Robert Flies (EU Commission, Environment DG).

In this special issue we focus on the session on "Biodiversity Conservation in Forests in Times of Climate Change", which hosted paper presentations based on theoretical considerations or case studies dealing with one or several of the following three aspects:

- Analysis of the main impacts of climate change on forest ecosystems, possible forest ecosystem responses and their relation to biodiversity conservation objectives.

- Identification of promising strategies to adapt biodiversity conservation and management in forests in light of climate change and related uncertainties.

- Evaluation of general principles, objectives and reference systems of biodiversity conservation in a changing climate.

Finally, we selected eight papers, which address core questions relating to the aforementioned aspects. The first two illustrate effects and quantify impacts of climate change on forest species and biodiversity with a focus on the distribution of invertebrates in forest ecosystems. Climate change can impact on the range dynamics of species and can induce shifts in their distribution patterns. Understanding and quantifying such climate change induced range shifts is important for conservation management and the planning of biotope corridors, but also for evaluating effects on newly colonized habitats and for guiding adaptation measures.

In the first paper of this issue, Buse et al. (2013) reconstructed the immigration of the oak-inhabiting jewel beetle Coraebus florentinus from Mediterranean forest ecosystems to Germany since the 1950s. Using three independent modelling approaches they analysed abiotic factors which determine the current spatial distribution of the beetle in southwest Germany. The authors link the range extension to the main factors of "mean maximum temperature" and "mean precipitation" in summer, which have both been altered by climate change during recent decades. The warmer and dryer conditions in southwest Germany favoured the reproduction and enabled the migration success of Coraebus florentinus. Considering current projections of climate change, the jewel beetle is expected to extend its range further north into Central Europe in the future and might particularly affect young oak stands on sandy and dry sites. This calls for an adaptation of forest management for the conservation of species-rich oak stands and a revision of the conservation status and categorization of the beetle as a critically endangered species in Germany.

The direct and indirect impacts of climatic alterations on Mediterranean forest ecosystems in Greece are the subject of the study by Chrysopolitou et al. (2013). Greece is projected to be among the most vulnerable countries to climate change in Europe. In this context, the presented study of climate change effects on the appearance of fungal pathogens and bark beetle populations as well as on woody vegetation composition could be a valuable contribution to the development of adaptation measures in Mediterranean forest ecosystems in general. The authors collected evidence for the link between alterations in temperature and precipitation regimes and the outbreaks of pathogens, which jointly caused the dieback of tree species (especially conifer species), in four different mountainous study areas in Greece. However, the impacts on tree species composition have varied between the different study areas which in turn calls for the development of regionalized adaptation measures within forest and conservation management and further research on the underlying driving forces. 
The subsequent three papers focus on adaptation strategies and measures for forest and conservation management aimed at mitigating the impacts of climate change on forest biodiversity. Together, these three contributions address the different aspects of biodiversity from the genetic diversity of tree species, via tree species composition to the structural diversity of forest stands and landscapes.

Genetic resources are a key component of biodiversity, but are also of particular importance for adaptation measures of forest ecosystems to climate change. Taking Norway Spruce in Austria as a case study, Schueler et al. (2013) analyse the genetic variation of this species in response to climate change and the shift in site characteristics. They discuss the effectiveness of a network of genetic conservation units in Austria to safeguard the genetic diversity of the species. The most promising provenances in terms of climate change adaptation are found in the warmest and driest areas of the Norway Spruce's distribution in Austria. This confirms the importance of the rear-edge populations for climate change adaptation and provides valuable hints for the evaluation of the effectiveness of current conservation efforts to protect genetic diversity.

In regions that are highly vulnerable to climate change, tree species shifts from less drought-resistant to more drought-resistant species can affect the biodiversity of forest ecosystems. How these species shifts are moderated and influenced by game populations and their browsing activities is the main research question of the contribution from Katona et al. (2013). The authors analysed data of understory species composition and browsing impact from five different even-aged forest ecosystems in Hungary. They found that nonnative, drought-resistant Robinia pseudoacacia, which is currently extending in Hungarian forests in the course of climate change, is highly preferred by browsing ungulates. In contrast, native species which are susceptible to climate change induced drought effects, such as Fagus sylvatica or various Quercus species, are selectively avoided. Hence, ungulate browsing might mitigate climate change induced effects on tree species composition and herbivore feeding preferences should play a vital role when climate change adaptation strategies are planned for the conservation of forest biodiversity.

Until now, there have been few strategies for adapting forest and conservation management to climate change and the transfer of science-informed knowledge to practice is still poorly developed as recommendations are often too general. However, in regions characterised by a high vulnerability to climate change, practitioners in forestry and conservation management already have to cope with the impacts of climate change. Against this backdrop, the article of Milad et al. (2013) analyses currently implemented and planned adaptation measures in forest management in Germany as well as the underlying motivations for their implementation. By conducting expert interviews with practitioners of different forest ownership classes in different regions in Germany the authors show that both regional vulnerability to climate change and personal values affect the implementation of adaptation measures. So far, adaptation measures are rather broad and are, above all, aimed at the reduction of risks related to forest production. The authors conclude that the development of consistent and regionalized adaptation strategies for forest management and the adequate transfer of these into practice are particularly important for conserving forest biodiversity in the context of climate change.

The last three articles address potential strategies and instruments of forest biodiversity conservation for coping with climate change and related challenges. These tackle this topic from different points of view and use rather diverse approaches, ranging from a classical review, via an empirical study of socio-cultural data to a model-based spatial analysis.

The extensive literature review of Pawson et al. (2013) analyses the direct and indirect impacts of climate change for plantation forests. Though often underestimated, plantation 
forests may contribute via their increasing area worldwide to biodiversity conservation by serving as secondary habitats as well as by reducing negative impacts on remaining primary forest ecosystems. Similar to other forest ecosystems, plantation forests will suffer from direct impacts of climate change such as higher storm and fire frequencies or outbreaks of pests and diseases. However, the authors conclude that the adaptation of forest management is likely to have greater effects on biodiversity in plantation forests than direct climate impacts. They advocate a landscape-level concept for the design and management of plantation forests to maximize the opportunities for biodiversity conservation of plantation ecosystems in a changing climate.

Provided adequate environmental safeguards are included, the international payment transfer mechanism to reduce greenhouse gas emissions from deforestation and forest degradation in developing countries, known as REDD+, could take on an important role in climate change mitigation as well as forest biodiversity conservation in the future. Taking REDD+ pilot projects in Peru as an example, Entenmann and Schmitt (2013) identify expectations and policy issues with regards to forest biodiversity conservation that are assigned to the instrument by different actors in this country. The authors reveal that most actors see direct links between REDD+ and biodiversity conservation. Biodiversity values mentioned by the actors were, above all, connected to direct or indirect uses. Aspects of biodiversity that are vital for the long-term integrity of forest ecosystems were not rated as equally important. This highlights the importance of integrating respective safeguards into the REDD+ mechanism.

In light of climate change, conservation priorities may shift. Thus, the systematic and efficient redirection of the limited resources available for biodiversity conservation will become increasingly important. In the last paper of this special issue, Freudenberger et al. (2013) propose an alternative tool to set global conservation priorities based on a modeling approach, which uses an array of ecological, economic and social indicators. The authors assume that priority should be given to functional ecosystems which provide a multitude of ecosystem services and have a high adaptive capacity to environmental change. Applying different prioritization categories in the model (e.g. also a ClimateWise pritoritization category) the authors recommend using a combination of ecological, socioeconomic indicators and proxies for vulnerability to climate change in the design of future global conservation strategies.

\section{Outlook}

What are the overarching lessons learnt that could guide the redirection of conservation strategies for forest biodiversity? Are there feasible adaptation strategies to safeguard forest biodiversity in the future? The compilation of papers in this issue demonstrates that research on the impacts of climate change on forest biodiversity can increase knowledge via empirical and modeling approaches. However, uncertainties concerning future climatic development and its impacts remain and conservation strategies have to find approaches to cope with those uncertainties and to integrate new knowledge systematically. The generation of diversity on different levels seems to be a key measure for adapting forest ecosystems to climate change. In the face of future uncertainties, conservation strategies should be actively pushed forward and should also comprise a diversity of actions in adaptive management within the scope of biodiversity conservation objectives. Such strategies could assist in maintaining the capacity for self-organization of forest 
ecosystems and hence their resilience (Berkes 2007). They can also help to secure a broad range of possible management options for the future.

The papers provide insight into regional and local variation in the impacts of climate change on forest ecosystems and biodiversity, which should be reflected in future conservation strategies and adaptation measures. In addition to site-specific measures on the small-scale, the landscape level has to be taken increasingly into account. This may determine different conservation objectives and measures on an overarching level. One central aspect in this sense is to increase the permeability of the landscape for different organisms through an increase in habitat diversity and less intensive land uses. Furthermore, the papers revealed that the adaptation of forest conservation strategies to climate change poses challenges for knowledge and decision management. Given the expected changes in site conditions, objectives and measures should be periodically evaluated or rediscussed and adjusted to new insights, according to an adaptive management approach. Such evaluations should be based on scientific findings resulting from models or scenario techniques, but also on management experiences and the local ecological knowledge of different actors and practitioners in forest and conservation management. The challenges for forest biodiversity conservation in forests posed by climate change can only be tackled adequately if different disciplines and different stakeholders collaborate in a constructive and innovative adaptation process.

Acknowledgments We would like to thank David L. Hawksworth for enabling and continuously supporting this special issue. We are very grateful to all the participating colleagues of our conference and to all the authors and reviewers for their valuable contributions to this special issue. Finally, we want to acknowledge the German Federal Ministry for the Environment, Nature Conservation and Nuclear Safety (BMU) for funding the conference on "Forest Biodiversity in a Changing Climate: Understanding Conservation Strategies and Policies" and the research project "Forests and Climate Change" (FKZ 350883 0600) through the German Federal Agency for Nature Conservation (BfN).

\section{References}

Berkes F (2007) Understanding uncertainty and reducing vulnerability: lessons from resilience thinking. Nat Hazards 41(2):283-295. doi:10.1007/s11069-006-9036-7

Buse J, Griebeler EM, Niehuis M (2013) Rising temperatures explain past immigration of the thermophilic oak-inhabiting beetle Coraebus florentinus (Coleoptera: Buprestidae) in south-west Germany. Biodivers Conserv 22. doi:10.1007/s10531-012-0395-y

Caparros A, Jacquemont F (2003) Conflicts between biodiversity and carbon sequestration programs: economic and legal implications. Ecol Econ 46(1):143-157. doi:10.1016/S0921-8009(03)00138-1

Chrysopolitou V, Apostolakis A, Avtzis D, Avtzis N, Diamandis S, Kemitzoglou D, Papadimos D, Perlerou C, Tsiaoussi V, Dafis S (2013) Studies on forest health and vegetation changes in Greece under the effects of climate changes. Biodivers Conserv 22. doi:10.1007/s10531-013-0451-2

Easterling DR, Meehl GA, Parmesan C, Changnon SA, Karl TR, Mearns LO (2000) Climate extremes: observations, modeling, and impacts. Science 289(5487):2068-2074. doi:10.1126/science.289.5487.2068

Entenmann SK, Schmitt CB (2013) Actors' perceptions of forest biodiversity values and policy issues related to REDD+ implementation in Peru. Biodivers Conserv 22. doi:10.1007/s10531-013-0477-5

Flannigan MD, Krawchuk MA, de Groot WJ, Wotton BM, Gowman LM (2009) Implications of changing climate for global wildland fire. Int J Wildland Fire 18(5):483-507. doi:10.1071/Wf08187

Freudenberger L, Hobson P, Schluck M, Kreft S, Vohland K, Sommer H, Reichle S, Nowicki C, Barthlott' W, Ibisch PL (2013) Nature conservation: priority-setting needs a global change. Biodivers Conserv 22. doi:10.1007/s10531-012-0428-6

Hampe A, Petit RJ (2005) Conserving biodiversity under climate change: the rear edge matters. Ecol Lett 8(5):461-467. doi:10.1111/j.1461-0248.2005.00739.x

Hannah L, Midgley G, Andelman S, Araujo M, Hughes G, Martinez-Meyer E, Pearson R, Williams P (2007) Protected area needs in a changing climate. Front Ecol Environ 5(3):131-138. doi:10.1890/1540-9295 
Hossell JE, Ellis NE, Harley MJ, Hepburn IR (2003) Climate change and nature conservation: implications for policy and practice in Britain and Ireland. J Nat Conserv 11(1):67-73

Jentsch A, Beierkuhnlein C (2008) Research frontiers in climate change: effects of extreme meteorological events on ecosystems. C R Geoscience 340(9-10):621-628

Jentsch A, Kreyling J, Beierkuhnlein C (2007) A new generation of climate-change experiments: events, not trends. Front Ecol Environ 5(7):365-374. doi:10.1890/1540-9295

Jump AS, Penuelas J (2005) Running to stand still: adaptation and the response of plants to rapid climate change. Ecol Lett 8(9):1010-1020. doi:10.1111/j.1461-0248.2005.00796.x

Katona K, Kiss M, Bleier N, Székely J, Nyeste M, Kovács V, Terhes A, Fodor Á, Olajos T, Rasztovits E, Szemethy L (2013) Ungulate browsing shapes climate change impacts on forest biodiversity in Hungary. Biodivers Conserv 22. doi: 10.1007/s10531-013-0490-8

Keith SA, Newton AC, Herbert RJH, Morecroft MD, Bealey CE (2009) Non-analogous community formation in response to climate change. J Nat Conserv 17(4):228-235. doi:10.1016/j.jnc.2009.04.003

Milad M, Schaich H, Bürgi M, Konold W (2011) Climate change and nature conservation in Central European forests: a review of consequences, concepts and challenges. Forest Ecol Manag 261:829-843. doi:10.1016/j.foreco.2010.10.038

Milad M, Schaich H, Konold W (2012a) Climate change adaptation measures - an analysis of proposals from forestry and nature conservation. Allgemeine Forst und Jagdzeitung 183(9-10):183-196

Milad M, Storch S, Schaich H, Konold W, Winkel G (2012b) Wälder und Klimawandel: Künftige Strategien für Schutz und nachhaltige Nutzung. Schriftenreihe Naturschutz und Biologische Vielfalt, Band 125. Bundesamt für Naturschutz, Bonn-Bad Godesberg

Milad M, Schaich H, Konold W (2013) How is adaptation to climate change reflected in current practice of forest management and conservation? A case study from Germany. Biodivers Conserv 22. doi: 10.1007/s10531-012-0337-8

Parmesan C (2006) Ecological and evolutionary responses to recent climate change. Annu Rev Ecol Evol Syst 37:637-669

Pawson SM, Brin A, Brockerhoff EG, Lamb D, Payn TW, Paquette A, Parrotta JA (2013) Plantation forests, climate change and biodiversity. Biodivers Conserv 22. doi:10.1007/s10531-013-0458-8

Penuelas J, Filella I (2001) Phenology-responses to a warming world. Science 294(5543):793-795. doi: $10.1126 /$ science. 1066860

Perera AH, Buse L, Crow TR (eds) (2006) Forest Landscape Ecology. Transferring Knowledge into Practice, Springer

Pistorius T, Schaich H, Winkel G, Plieninger T, Bieling C, Konold W, Volz KR (2012) Lessons for REDDplus: a comparative analysis of the German discourse on forest functions and the global ecosystem services debate. Forest Policy Econ 18:4-12. doi:10.1016/j.forpol.2011.09.001

Rehfeldt GE, Wykoff WR, Ying CC (2001) Physiologic plasticity, evolution, and impacts of a changing climate on Pinus contorta. Climatic Change 50(3):355-376. doi:10.1023/A:1010614216256

Schaich H (2013) Instrumente des Waldnaturschutzes und die Rolle von Ökosystemleistungen. In: Ring I (ed) Der Nutzen von Ökonomie und Ökosystemleistungen für die Naturschutzpraxis-Workshop III: Wälder. BfN-Skripten 334. Bundesamt für Naturschutz, Bonn-Bad Godesberg, pp 44-55

Schaich H, Konold W (2012) Remuneration of ecological services in forestry-new options for compensation measures in forests? Naturschutz und Landschaftsplanung 44(1):5-13

Schueler S, Kapeller S, Konrad H, Geburek T, Mengl M, Bozzano M, Koskela J, Lefèvre F, Hubert J, Kraigher H, Longauer R, Olrik DC (2013) Adaptive genetic diversity of trees for forest conservation in a future climate: a case study on Norway spruce in Austria. Biodivers Conserv 22. doi:10.1007/ s10531-012-0313-3

Skov F, Svenning JC (2004) Potential impact of climatic change on the distribution of forest herbs in Europe. Ecography 27(3):366-380. doi:10.1111/j.0906-7590.2004.03823.x

Thomas CD, Cameron A, Green RE, Bakkenes M, Beaumont LJ, Collingham YC, Erasmus BFN, de Siqueira MF, Grainger A, Hannah L, Hughes L, Huntley B, van Jaarsveld AS, Midgley GF, Miles L, Ortega-Huerta MA, Peterson AT, Phillips OL, Williams SE (2004) Extinction risk from climate change. Nature 427(6970):145-148. doi:10.1038/Nature02121 